Research Article

\title{
Evaluation of the genotoxic and antigenotoxic potential of Melissa officinalis in mice
}

Natália Cassettari de Carvalho ${ }^{1}$, Maria Júlia Frydberg Corrêa-Angeloni ${ }^{1}$, Daniela Dimer Leffa ${ }^{1}$, Jeverson Moreira $^{2}$, Vanessa Nicolau ${ }^{2}$, Patrícia de Aguiar Amaral2 ${ }^{2}$, Ângela Erna Rossatto ${ }^{2}$ and Vanessa Moraes de Andrade ${ }^{1}$

${ }^{1}$ Laboratório de Biologia Celular e Molecular, Programa de Pós-Graduação em Ciências da Saúde, Unidade Acadêmica de Ciências da Saúde, Universidade do Extremo Sul Catarinense, Criciúma, SC, Brazil. ${ }^{2}$ Laboratório de Estudos Etnofarmacológicos, Curso de Farmácia, Unidade Acadêmica de Ciências da Saúde, Universidade do Extremo Sul Catarinense, Criciúma, SC, Brazil.

\begin{abstract}
Melissa officinalis (L.) (Lamiaceae), a plant known as the lemon balm, is native to the east Mediterranean region and west Asia. Also found in tropical countries, such as Brazil, where it is popularly known as "erva-cidreira" or "melissa", it is widely used in aqueous- or alcoholic-extract form in the treatment of various disorders. The aim was to investigate in vivo its antigenotoxicity and antimutagenicity, as well as its genotoxic/mutagenic potential through comet and micronucleus assaying. CF-1 male mice were treated with ethanolic (Mo-EE) (250 or $500 \mathrm{mg} / \mathrm{kg}$ ) or aqueous (Mo-AE) $(100 \mathrm{mg} / \mathrm{kg})$ solutions of an $M$. officinalis extract for 2 weeks, prior to treatment with saline or Methyl methanesulfonate (MMS) doses by intraperitoneal injection. Irrespective of the doses, no genotoxic or mutagenic effects were observed in blood and bone-marrow samples. Although Mo-EE exerted an antigenotoxic effect on the blood cells of mice treated with the alkylating agent (MMS) in all the doses, this was not so with Mo-AE. Micronucleus testing revealed the protector effect of Mo-EE, but only when administered at the highest dose. The implication that an ethanolic extract of $M$. officinalis has antigenotoxic/antimutagenic properties is an indication of its medicinal relevance.
\end{abstract}

Key words: Melissa officinalis, comet assay, micronucleus test, genotoxicity, antigenotoxicity.

Received: September 11, 2010; Accepted: February 17, 2011.

\section{Introduction}

Medicinal plants and their derived forms (extracts, syrups, etc.) have been the basis of medical therapy for centuries. Traditionally used in the treatment of several human disorders, their pharmacological and therapeutic properties are attributed to various chemical constituents isolated from their crude extracts (Pereira et al. 2009). Notwithstanding, their correct use requires the manipulation of plants selected for their efficacy and safety, based either on folk tradition or scientific validation (Tovart, 2009). The use of herbal infusions to cure various disorders is very common in Brazilian folk medicine, often replacing modern forms. Although the diversity of plant species in Brazil is a potential source of biologically active compounds, the effects on human health and genetic material are often unknown. Not all are harmless, some even presenting toxic

Send correspondence to Vanessa Moraes de Andrade. Laboratório de Biologia Celular e Molecular, Universidade do Extremo Sul Catarinense, Av. Universitária 1105, Bairro Universitário, 88806-000 Criciúma, SC, Brazil. E-mail: vmoraesdeandrade@yahoo.com.br. and mutagenic substances in their phytochemical composition (Bresolin and Vargas, 1993; Sá-Ferreira and Vargas, 1999; Fernandes and Vargas, 2003). On the other hand, there are indications that the protective action on genetic material can lead, not only to its repair, but also the preservation of its integrity (Berhow et al. 2000; Fernandes and Vargas, 2003; Souza et al. 2004). Interest in such popular usage has recently gained strength, through recent knowledge that chemicals, such as proteases and antioxidants may prevent or reduce the development of cancer by blocking genetic damage (Berhow et al. 2000; Hernández-Ceruelos et al. 2002; Souza et al. 2004).

Originally native to the east Mediterranean region and west Asia, Melissa officinalis (L.) (Lamiaceae) (lemon balm) is also encountered in certain tropical countries, such as Brazil, where it is popularly known as 'erva-cidreira' and 'melissa' (Souza et al. 2004). Aqueous and alcoholic extracts from the aerial part of Melissa officinalis are traditionally used in the treatment of fevers and colds, indigestion associated with nervous tension, hyperthyroidism, depression, mild insomnia, epilepsy, headaches, tooth- 
aches, and so on (Carnat et al. 1998; Herodez et al. 2003; Salah and Jäger, 2005; Dastmalchi et al. 2008). Furthermore, its antioxidant activity has been described by various authors (Mimica-Dukic et al. 2004; Souza et al. 2004; Canadanovic-Brunet et al. 2008).

Phytochemical studies carried out with M. officinalis have demonstrated the numerous constituents, viz., polyphenolic compounds (rosmarinic acid, caffeic acid and protocatechuic acid), essencial oils (citral), monotherpenoid aldehides, sesquiterpenes, flavonoids (luteolin) and tannins (Carnat et al. 1998; Guginski et al. 2009). Pharmacological investigation concerning its essential oil has revealed that, besides this being an efficient antibacterial and antifungal agent (Mimica-Dukic et al. 2004), it is also endowed with intrinsic anxiolytic properties (Pereira et al. 2005). The antioxidant and antitumoral properties are implied from a literature that is mainly addressed to core components, other than extracts or infusions per se (Souza et al. 2004; Pereira et al. 2009).

It is worth while emphasizing that, in many studies, only the effects of isolated phytochemicals and complete mixtures in in vitro tests are taken into consideration. In most cases the antimutagenic action attributed to certain plants is, in fact, due to intrinsic compounds, mainly flavonoids (Czeczot and Kusztelak, 1993; Hernández-Ceruelos et al. 2002; Gomes-Carneiro et al. 2005).

However, data concerning the action of complex mixtures, such as teas and juices of vegetable and fruit origin, the predominant form of intake, are scarce, whereby the importance of their study. Considering the widespread therapeutic usage of Melissa officinalis, mainly in south Brazil, the aim was to investigate the mutagenic and genotoxic activities of its aqueous and ethanolic extracts, by way of micronucleus testing and comet assaying. In their absence, the antimutagenic and antigenotoxic potential were also investigated.

\section{Material and Methods}

\section{Plant material}

Aerial parts of $M$. officinalis were collected in Grão Pará, SC, Brazil in September 2008. A voucher specimen (number CRI 7380) was deposited at the Herbarium Pe. Dr. Raulino Reitz, Universidade do Extremo Sul Catarinense, Criciúma, SC, Brazil. The parts were allowed to dry under air circulation $\left(40^{\circ} \mathrm{C}\right)$ for 3 days.

\section{Preparation of extracts}

The ethanolic extract was obtained according to methodology proposed by the Brazilian Pharmacopoeia (Farmacopéia Brasileira, 2001). This was prepared by soaking $200 \mathrm{~g}$ of dried pharmacogen (ground in a knife mill) in $1 \mathrm{~L}$ of solvent (water-alcohol solution of ethanol $45 \%$ ) for about 15 days at room temperature, protected from the light, with stirring once a day, and no renewal of the liquid extractor. The liquid product was then gauze-strained and filtered, to then be completed to a volume of $1000 \mathrm{~mL}$ with the same solvent. The extract was first evaporated to dryness under reduced pressure, whereupon the dry form was diluted in water, in order to furnish two different doses for testing (250 and $500 \mathrm{mg} / \mathrm{kg}$ ) (Müzell, 2006). This aqueous extract was obtained by infusion of $0.6 \mathrm{~g}$ of dry pharmacogen in $20 \mathrm{~mL}$ of distilled hot water, immediately before use, its dose $(100 \mathrm{mg} / \mathrm{kg})$ being based on the calculation of total solids.

\section{Phytochemical screening}

Phytochemical analysis of flavonoids, tannins, anthraquinones, alkaloids, saponins, coumarins and cardiac glycosides, from the aerial parts of the plant was according to methods described by Harborn (1998). Thin-layer chromatography analysis was according to Wagner and Bladt (2009). The aluminum chloride colorimetric method was used for the quantitative determination of flavonoids (Farmacopéia Brasileira, 2001). Each plant extract in methanol $(0.5 \mathrm{~mL}$ of $1: 10 \mathrm{~g})$ was separately mixed with $1.5 \mathrm{~mL}$ of methanol, $0.5 \mathrm{~mL}$ of $2 \%$ aluminum chloride, $0.1 \mathrm{~mL}$ of $1 \mathrm{M}$ potassium acetate and $2.8 \mathrm{~mL}$ of distilled water. After standing at room temperature for $30 \mathrm{~min}$, reaction-mixture absorbance was measured at $425 \mathrm{~nm}$ with a biospectro Model SP-22 UV/Visible spectrophotometer.

\section{Animals and treatments}

CF-1 male mice (weighing 40-50 g) were obtained from the breeding colonies of the University of South Santa Catarina, UNESC, Criciúma, SC, Brazil. The animals were kept in plastic cages in an experimental room under controlled conditions of temperature $\left(22 \pm 2{ }^{\circ} \mathrm{C}\right)$, humidity (55 $\pm 10 \%), 12$-h light/dark cycles and ad libitum access to food and water. They were randomized at the beginning of the experiment. The study design was approved by the Animal Ethical Committee of UNESC (protocol number 043/2008), and the experiments undertaken in accordance with the ethical principles of the Brazilian College of Animal Experimentation - COBEA.

The mice were divided into 7 groups, with 5 animals per group. Methyl methanesulfonate (MMS, SigmaAldrich) was used to induce mutations and DNA damage for antimutagenic/antigenotoxic evaluation. Just before use, the MMS was diluted in $0.9 \% \mathrm{NaCl}$. The exposure route was by intraperitoneal (ip) injection $(40 \mathrm{mg} / \mathrm{kg} \mathrm{b.w})$. Evaluation of either DNA damage or protection by the aqueous and ethanolic extracts of M. officinalis, was according to protocol developed by Azevedo et al. (2007), with the following adaptations (Figure 1): The mice in group 1 received only distilled water $(10 \mathrm{~mL} / \mathrm{kg}$ b.w. per day by gavage) for 2 weeks prior to treatment with $0.9 \%$ $\mathrm{NaCl}$ by intraperitoneal (i.p.) injection. Although they also received distilled water ( $10 \mathrm{~mL} / \mathrm{kg}$ b.w. per day by gavage) for 2 weeks, those in group 2 were treated with MMS 


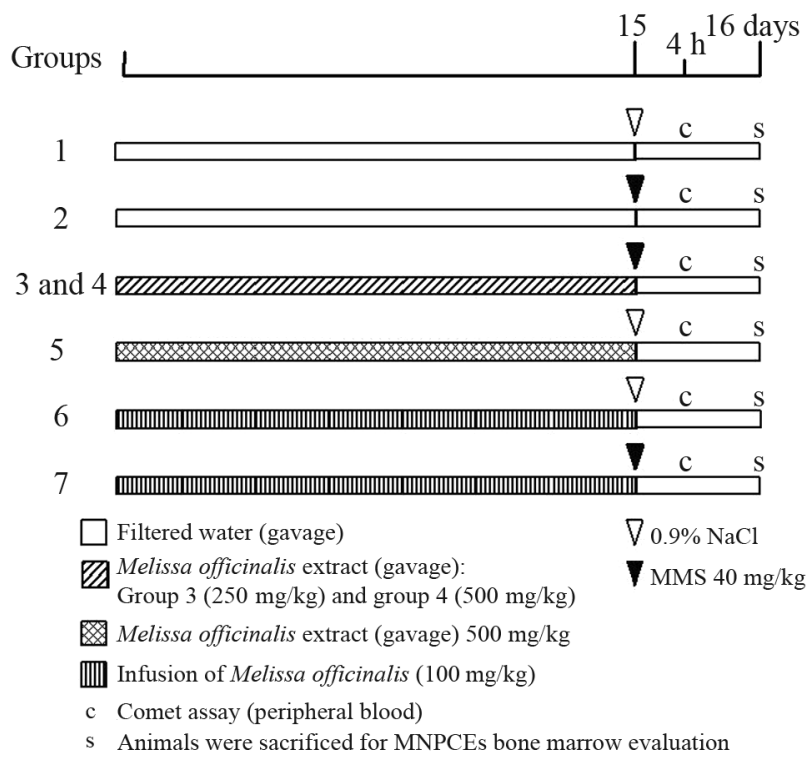

Figure 1 - The antimutagenicity and antigenotoxicity of an Melissa officinalis extract in mutagen-induced micronulei.

$\left(40 \mathrm{mg} / \mathrm{kg}\right.$ b.w.) on the $15^{\text {th }}$ day. Individuals in groups 3 and 4 received an $M$. officinalis ethanolic extract $(10 \mathrm{~mL} / \mathrm{kg}$ b.w. per day by gavage), prepared in two different doses, $250 \mathrm{mg} / \mathrm{kg}$ (group 3) and $500 \mathrm{mg} / \mathrm{kg}$ (group 4), for 2 weeks prior to treatment with MMS. Individuals in group 5 received only a Melissa officinalis ethanolic extract $(500 \mathrm{mg} / \mathrm{kg}$ by gavage) prior to a $0.9 \% \mathrm{NaCl}$ i.p. injection on the $15^{\text {th }}$ day. Individuals in groups 6 and 7 received the aqueous extract of Melissa officinalis (100 mg/kg), $10 \mathrm{~mL} / \mathrm{kg}$ b.w. per day by gavage, for 2 weeks prior to a $0.9 \% \mathrm{NaCl}$ or MMS i.p. injection on the $15^{\text {th }}$ day. The mice were killed by cervical dislocation, $24 \mathrm{~h}$ after treatment, for evaluation of micronucleated polychromatic erythrocytes (MNPCEs) in the bone-marrow. For comet assaying, samples of peripheral blood were collected from mouse tail-tips by a slight incision, $4 \mathrm{~h}$ after MMS treatment.

\section{Comet assay}

Single-Cell Gel Electrophoresis, or the comet assay, is a highly sensitive method for assessing DNA damage formation and repair, both at clinically relevant and low doses. Alkaline-comet assaying was undertaken as described by Singh et al. (1988). Peripheral blood samples were collected from the tail of each animal in heparinized microtubes, $4 \mathrm{~h}$ after MMS treatment. Briefly, $5 \mu \mathrm{L}$ of whole blood was embedded in a layer consisting of $95 \mu \mathrm{L}$ of $0.75 \%$ low-melting-point agarose gel on frosted slides, and then immersed in a lysis buffer $(2.5 \mathrm{M} \mathrm{NaCl}, 100 \mathrm{mM}$ EDTA, and $10 \mathrm{mM}$ Tris [pH 10.0-10.5] with freshly added $1 \%$ Triton X-100 and 10\% dimethyl sulfoxide), for a minimum of $1 \mathrm{~h}$ and a maximum of one week. Subsequently, the slides were incubated in a freshly prepared alkaline buffer (300 mM NaOH and $1 \mathrm{mM}$ EDTA, $\mathrm{pH}>13$ ) for $20 \mathrm{~min}$.
The nuclei were electrophoresed for $20 \mathrm{~min}$ at $25 \mathrm{~V}$ $(0.90 \mathrm{~V} / \mathrm{cm})$ and $300 \mathrm{~mA}$, whereupon the alkali was neutralized with $0.4 \mathrm{M}$ Tris ( $\mathrm{pH}$ 7.5). After neutralization, the slides were fixed $(15 \% \mathrm{w} / \mathrm{v}$ trichloroacetic acid, $5 \% \mathrm{w} / \mathrm{v}$ zinc sulfate, $5 \%$ glycerol), washed in distilled water, and dried overnight. The gels were re-hydrated for $5 \mathrm{~min}$ in distilled water, and then stained for $15 \min \left(37^{\circ} \mathrm{C}\right)$ with a solution containing the following sequence: $34 \mathrm{~mL}$ of Solution B $(0.2 \% \mathrm{w} / \mathrm{v}$ ammonium nitrate, $0.2 \% \mathrm{w} / \mathrm{v}$ silver nitrate, $0.5 \% \mathrm{w} / \mathrm{v}$ tungstosilicic acid, $0.15 \% \mathrm{v} / \mathrm{v}$ formaldehyde, $5 \%$ $\mathrm{w} / \mathrm{v}$ sodium carbonate) and $66 \mathrm{~mL}$ of Solution A (5\% sodium carbonate). The staining was stopped with $1 \%$ acetic acid, whereupon the gels were air-dried (Villela et al. 2006). The visual classification method of Collins et al. (1997) was applied to assess the extent of DNA damage. Cells were scored from 0 (undamaged) to 4 (maximally damaged), according to tail intensity (size and shape), this resulting in a single DNA damage score (damage index) for each sample and, consequently, for each group. Thus, a damage index (DI) of the group could range from 0 (completely undamaged) 100 cells (x 0) to 400 (maximum damage) 100 cells (x 4). The percentage of damage frequency (DF) was calculated for each sample on the basis of the number of cells with a tail versus those without.

\section{The micronucleus test}

Micronucleus assaying was according to the U.S. Environmental Protection Agency Gene-Tox Program (Mavournin et al. 1990). Slides were prepared from smears of bone-marrow from both femurs, suspended in foetal calf serum. These were air-dried, xed in methanol, stained in $10 \%$ Giemsa and then coded for blind analysis. One thousand polychromatic erythrocytes were analyzed per mouse. The proportion of PCE and NCE (normochromatic erythrocytes) in 200 erythrocytes/animal was calculated, to detect possible cytotoxic effects. The slides were scored blindly, using a light microscope with a 100x immersion objective.

\section{Statistical analysis}

Variable normality was assessed using the Kolmogorov-Smirnov test. Micronucleus testing and comet assaying involved multiple pair-wise comparison between experimental groups and positive and negative controls, with the Student $t$-test at a significance level of 0.05 . The statistical package applied was BioEstat 5.0. The percentage of reduction in the frequency of MMS induced DNA damage was calculated according to Azevedo et al. (2003) and Waters et al. (1990).

\section{Results}

The phytochemical analysis of the $M$. officinalis extract (Table 1) indicated the presence of fenolic compounds, tannins, flavonoids, alkaloids and coumarins, but not of other secondary metabolites, such as anthraquinones and saponins. 
Table 1 - Phytochemical screening.

\begin{tabular}{|c|c|}
\hline Test & Melissa officinalis \\
\hline \multicolumn{2}{|l|}{ Phenolic compounds } \\
\hline $\mathrm{W}-\mathrm{Ext}+\mathrm{KOH} 3 \%$ & + \\
\hline $\mathrm{W}-\mathrm{Ext}+\mathrm{FeCl}_{3} 1 \%$ & + \\
\hline \multicolumn{2}{|l|}{ Tannins } \\
\hline W-Ext + gelatine & - \\
\hline $\mathrm{W}-\mathrm{Ext}+\mathrm{FeCl}_{3} 3 \%$ & + \\
\hline \multicolumn{2}{|l|}{ Flavonoids qualitative } \\
\hline $\mathrm{W}-\mathrm{Ext}+\mathrm{MgO} / \mathrm{HCl}$ & + \\
\hline \multicolumn{2}{|l|}{ Flavonoids quantitative UV $425 \mathrm{~nm}$} \\
\hline $\mathrm{CH}_{3} \mathrm{OH}-\mathrm{Ext}$ & 0.572 \\
\hline \multicolumn{2}{|l|}{ Alkaloids } \\
\hline W-Ext + Mayers Reagent & - \\
\hline W-Ext + Bertrand's Reagent & - \\
\hline W-Ext + Dragendorff's Reagent & - \\
\hline W-Ext + Bouchard's Reagent & + \\
\hline \multicolumn{2}{|l|}{ Antraquinones } \\
\hline $\mathrm{W}-\mathrm{Ext}+\mathrm{KOH} 3 \%$ & - \\
\hline \multicolumn{2}{|l|}{ Coumarins } \\
\hline $\mathrm{CH}_{3} \mathrm{CH}_{2} \mathrm{OH}-\mathrm{Ext}+\mathrm{KOH} / \mathrm{UV} 365 \mathrm{~nm}$ & + \\
\hline \multicolumn{2}{|l|}{ Saponins } \\
\hline $\mathrm{W}$-Ext $+\mathrm{HCl}$ (persistent foam) & - \\
\hline
\end{tabular}

W-Ext - water extract./ $\mathrm{CH}_{3} \mathrm{OH}-\mathrm{Ext}-$ methanol extract / $\mathrm{CH} 3 \mathrm{CH} 2 \mathrm{OH}-\mathrm{Ext}-$ ethanol extract / (-)negative / (+)positive.

According to comet assay results, DNA damage in both parameters (damage index and frequency) in mouse peripheral blood, following ingestion of $500 \mathrm{mg} / \mathrm{kg}$ of an ethanol extract (Mo-EE) and $1.000 \mathrm{mg} / \mathrm{kg}$ of an aqueous extract (Mo-AE), both of M. officinalis, during the 15 days of treatment, presented no statistically significant difference (Table 2). Thus, it can be deduced that in both treatments, genotoxic effects on mouse peripheral blood cells were null. When the antigenotoxicity of both was evaluated, a significant decrease in MMS-induced DNA damage (DI and DF) was observed in mice receiving $250 \mathrm{mg} / \mathrm{kg}$ and $500 \mathrm{mg} / \mathrm{kg}$ of Mo-EE. The reduction in the former case was $19.3 \%$ (Student t-test, $\mathrm{p}<0.05$ ) for DF, and 34.8\% (Student t-test, $\mathrm{p}<0.01)$ for DI, in relation to the positive control (MMS $40 \mathrm{mg} / \mathrm{kg}$ ), and in the latter 53.4\% (Student t-test, $\mathrm{p}<0.001$ ) and $46.2 \%$ (Student t-test, $\mathrm{p}<0.05$ ) for DF and DI, respectively. The analysis of DNA damage after pretreatment with the Mo-AE extract and Mo-EE infusion, indicated no diminution in MMS chemically induced DNA damage.

According to $\mathrm{MN}$ testing of mouse bone-marrow cells the low frequencies of micronucleated cells presumes the meager effects of Mo-EE $500 \mathrm{mg} / \mathrm{kg}$ and Mo-AE pretreatments (Table 3), thereby indicating the virtual absence of mutagenic or cytotoxic effects. In other words, no statistically significant difference in the frequency of MN PCE or the ratio of PCE to NCE, between the negative control and the groups that ingested extracts could be detected. When evaluating antimutagenicity in Mo-EE and Mo-AE, a significant decrease in the frequency of MMS-induced MNPCE was observed only in mice that had received $500 \mathrm{mg} / \mathrm{kg}$ of Mo-EE ( $\mathrm{p}=0.05$ - Student t-test). Likewise, for Mo-AE, there was no statistically significant reduction in the frequency of MN PCE.

\section{Discussion}

Over recent years, it has been widely reported that diet is a highly important factor in terms of either cancer induction or prevention. As already known, certain dietary micronutrients, such as flavonoids, carotenoids and others, can play an important role in the modulation or prevention of cancer development (World Cancer Research Fund, 2008). The ingestion of plant extracts with medicinal properties represents a plausible alternative in the treatment of various pathological states in economically unprivileged countries. However, in the absence of a scientific basis,

Table 2 - Detection of lesions in DNA (mean \pm SD) using the comet assay (DF and DI) in peripheral blood cells of mice exposed to methyl methanesulfonate (MMS, $40 \mathrm{mg} / \mathrm{kg}$ ) and different doses of Melissa officinalis.

\begin{tabular}{lccccc}
\hline Treatments & \multicolumn{4}{c}{ Comet assay } \\
\cline { 2 - 6 } & Number of animals & DF & \% reduction & DI & \% reduction \\
\hline Negative Control & 5 & $10.2 \pm 2.58$ & & $10.2 \pm 2.58$ & - \\
Positive Control & 5 & $83.8 \pm 9.44$ & & $134.4 \pm 29.03$ & - \\
Mo-EE 250 mg + MMS & 5 & $69.6 \pm 6.84^{\mathrm{a}}$ & 19.29 & $91.2 \pm 13.84^{\mathrm{b}}$ & 34.78 \\
Mo-EE 500 mg + MMS & 5 & $44.5 \pm 15.41^{\mathrm{c}}$ & 53.39 & $77 \pm 36.09^{\mathrm{a}}$ & 46.21 \\
Mo-EE 500 mg + saline & 5 & $10 \pm 2.54$ & & $13.8 \pm 2.68$ & - \\
Mo-AE + saline & 5 & $12.4 \pm 2.7$ & & $14.8 \pm 3.42$ & - \\
Mo-AE + MMS & 5 & $68.4 \pm 20.5$ & & $172 \pm 101.36$ & - \\
\hline
\end{tabular}

$\mathrm{SD}=$ standard deviation; $\mathrm{DF}=$ damage frequency; $\mathrm{DI}=$ damage index; $\mathrm{Mo}-\mathrm{EE}=$ Eehanol extract of Melissa officinalis; $\mathrm{Mo}-\mathrm{AE}=$ aqueous extract of M. officinalis. ${ }^{\mathrm{a}}$ Values differing significantly from positive control, $\mathrm{p}<0.05$ (Student $\mathrm{t}$-test) ${ }^{\mathrm{b}} \mathrm{p}<0.01,{ }^{\mathrm{c}} \mathrm{p}<0.001$. 
Table 3 - Effects of Melissa officinalis pre-treatments (gavage) on MNPCE frequencies (mean \pm SD) in the bone marrow of mice, following intraperitoneal injection with saline or methyl methanesulfonate (MMS) $40 \mathrm{mg} / \mathrm{kg}$.

\begin{tabular}{lcccc}
\hline Treatment & Number of analyzed cells & PCE/NCE ratio & MNPCEs & p values \\
\hline Negative Control & 1000 & $230.6 \pm 4.51$ & $3.6 \pm 0.89$ & - \\
Positive Control & 1000 & $231.8 \pm 7.73$ & $5.2 \pm 1.79$ & $0.05^{\mathrm{a}}$ \\
Mo-EE 250 mg + MMS & 1000 & $233.8 \pm 9.42$ & $3.6 \pm 1.67$ & 0.09 \\
Mo-EE 500 mg + MMS & 1000 & $239.0 \pm 3.46$ & $2.5 \pm 2.52$ & $0.05^{\mathrm{a}}$ \\
Mo-EE 500 mg + saline & 1000 & $236.8 \pm 7.89$ & $3.2 \pm 2.28$ & - \\
Mo-AE + saline & 1000 & $227.0 \pm 5.39$ & $3.2 \pm 1.79$ & - \\
Mo-AE + MMS & 1000 & $226.4 \pm 5.13$ & $6.4 \pm 1.67$ & 0.15 \\
\hline
\end{tabular}

Mo-EE $=$ ethanolic extract of Melissa officinalis; $\mathrm{Mo}-\mathrm{AE}=$ aqueous extract of $M$. officinalis $\mathrm{PCE}=$ polychromatic erythrocytes $\mathrm{NCE}=$ normochromatic erythrocytes. ${ }^{a}$ Values differing significantly from positive control (Student t-test).

such usage may give rise to serious adverse effects (Souza et al. 2004). An evaluation of the role of plant extracts, infusions and the main relevant phytochemical antigenotoxic and antimutagenic compounds involved, is essential, through the evidential participation of the latter in the prevention of cancer and other disorders (Berhow et al. 2000; Surh and Fergunson, 2003; Patel et al. 2007). In this study, the efficacy of two different extracts of $M$. officinalis against a well-known genotoxic compound, were tested. The aim was to investigate new potential antigenotoxic agents from natural sources, for possible use in prevention.

M. officinalis is invested with compounds with antioxidant, antinociceptive and antitumoral properties (Sousa et al. 2004; Canadanovic-Brunet et al. 2008; Guginski et al. 2009; Pereira et al. 2009). However, as to date no intrinsic antigenotoxic activity has been demonstrated., an investigation was undertaken, not only of this aspect, but also of possible antimutagenic and antigenotoxic effects against DNA damage induced by MMS, an alkylating agent.

Through comet assaying, the first and extremely important observation was the absence of DNA strand breaks, as well as the induced formation of micronuclei in mice that had received two kinds of $M$. officinalis extract. Furthermore, comet assaying and $\mathrm{MN}$ testing indicated the absence of genotoxic or mutagenic properties in ethanolic and aqueous extracts, respectively. Pereira et al. (2005) and Furtado et al. $(2008,2010)$ are alone in evaluating the genotoxic activity of a certain compound present in M. officinalis, viz., rosmarinic acid (RA). The former showed, through comet assaying, that in brain and peripheral blood samples from rats treated with RA and sacrified $3 \mathrm{~h}$ later, there were no significant differences in any of the parameters used to assess DNA damage, in comparison with the vehicle-treated control group. The second group investigated the capacity of RA to prevent chemically induced chromosome breakage and DNA damage, using the same assays as in the present study, although with V79 cells (Furtado et al. 2010). It was shown that, although exerting no genotoxic effect, RA significantly reduced micronucleus frequency and the extent of DNA damage induced by doxorubicin. With micro- nucleus assaying, Furtado et al. (2008) evaluated both the mutagenic and antimutagenic potential of RA on peripheral blood cells in Swiss mice. On the other hand, mutagenic assaying revealed no increase in micronuclei frequency in animals treated with various concentrations of RA, when compared to negative controls, whereas in treatments with these concentrations combined with DXR, there was a significant reduction in micronucleus frequency compared to animals treated with DXR alone.

On investigating the protective effect of $M$. officinalis in peripheral blood cells by comet assaying, and in bonemarrow PCE by MN testing, it was clearly indicated that an M. officinalis ethanolic extract was more efficient in reverting the antigenotoxic damage (comet assaying) than antimutagenic damage (MN testing) induced by MMS. However, as revealed by both test forms, the aqueous extract obtained from the infusion of M. officinalis in hot water (as a tea) was ineffective.

The already described antioxidant activity of $M$. officinalis extracts (Mimica-Dukic et al. 2004; Canadanovic-Brunet et al. 2008; Pereira et al. 2009), has been attributed mainly to intrinsic phenolic compounds. These form one of the largest and most ubiquitous groups of plant metabolites, their antioxidant, anti inflammatory, antimutagenic and anticarcinogenic activities currently being of widespread interest (Atoui et al. 2005; Franke et al. 2005; Geetha et al. 2005). Pereira et al. (2009) used encephalic tissue in the thiobarbituric acid reactive substances (TBARS) assay and determined the quantity of phenolic compounds in the plant extracts, in order to verify a possible relationship with antioxidant activity. They found that an aqueous extract of $M$. officinalis was the most active against TBARS production induced by all the tested agents, when compared with ethanolic and methanolic extracts therefrom. Interestingly, the inhibition of lipid peroxidation by the three increased with phenol content. However, in the 1'-1' diphenyl-2' picrylhydrazyl (DPPH) method, the three different extracts obtained from this plant (aqueous, ethanolic and methanolic) presented similar antioxidant potential. Furthermore, Mimica-Dukic et al. (2004), when ex- 
amining the oil of this plant, noted that, besides possessing high radical scavenging capacity, it exerted outstanding protective activity in lipid peroxidation processes. This was found to be positively correlated with a mainly monoterpene ketone and aldehyde content. These results are in accordance with data reported by other authors, thereby demonstrating that the antioxidant activity of certain Lamiaceae species, fruits and vegetables correlated positively with phenolic compound content (Ivanova et al. 2005; Katalinic et al. 2006; Pérez-Pérez et al. 2006).

In the present study, the ethanolic extract of $M$. officinalis presented both antigenotoxic and antimutagenic activities. As phenolic compounds have been shown to be endowed with these antioxidant properties, their involvement can be inferred.

Phenolic compounds are capable of protecting biological systems in various ways (Edenharder et al. 2002; Kelly et al. 2003). They have a dual effect on phase I and phase II enzymes, repressing some (mainly in phase I) and stimulating others (mainly in phase II) (Szaefer et al. 2004). Certain flavonoids, such as hesperetin, can selectively inhibit human cytochrome P450, thereby reducing the absorption or elimination of toxic compounds (Doostdar et al. 2000). Other phenolic compounds, such as limonoids, are inducers of the detoxifying enzyme gluthatione S-transferase. The stimulation of detoxifying enzymes can facilitate the elimination of toxic compounds, thereby significantly affecting the toxic potential of endogenous and exogenous chemicals (Kelly et al. 2003). However, since MMS is a directly acting alkylant, thus not requiring metabolic activaton, the antimutagenic activity of $M$. officinalis is not due to interaction with activating enzymes (Lima et al. 2001). Franke et al. (2005), with the aim of evaluating whether orange juice could reduce DNA damage induced by MMS in mice, showed that, under their experimental conditions, this really occurred. The authors showed that the components of orange juice are biologically effective, including in the role of targets for toxicants and in modulating metabolization/detoxification routes.

It is likely that phenolic compounds can be methylated by alkylating agents, instead of conjugation enzymes, thereby protecting reducing DNA from alkylation. MMS can methylate nucleophilic regions of DNA, as well as amino acid molecules, especially in nitrogen atoms. The methylation of phosphate groups accounts for a minor percentage of total MMS methylation $(<1 \%)$. MMS genotoxicity is mediated by base modifications, which weaken the N-glycosylic bond, thereby leading to depurination/depyrimidination of DNA strands and the appearance of alkali-labile abasic sites (AP sites). The removal of AP sites by AP endonucleases cleaves the DNA adjacent to these sites, thereby generating DNA strand breaks (Horvathova et al. 1998; Boiteux and Guillet, 2004; Franke et al. 2005). To a minor extent, MMS can also act as a weak oxidative stress inducer, as observed by Horvathova et al. (1998), who tested the effect of a synthetic antioxidant (Stobadine, SBT) in this case.

Two assays were undertaken to elucidate the mechanism of antigenotoxic/antimutagenic action in $M$. officinalis. An antimutagenic effect, as revealed by $\mathrm{MN}$ testing, could mainly be due to either the diminished induction of damage or increased repair. Through comet assaying, it was possible to measure the amount of DNA damage after treatment with a mutagen, thereby indicating whether an antigenotoxic effect is due to the reduced formation of primary DNA lesions or not. Herein, it was possible to show their obvious induction by MMS, as well as to demonstrate that these effects can be reduced by pre-treatment with an ethanolic extract. On the other hand, MN testing revealed a significant reduction only at the highest dose of the extract. Consequently, an M. officinalis extract was effective in preventing MMS-induced DNA lesions. In the pretreatment, phenolic compounds maybe competed as target sites for alkylation, whereas the absence of protection by the M. officinalis, aqueous extract against the frequency of DNA lesions and mutations induced by MMS, could be due to possible interactions among the compounds contained within the extract itself.

Taken together, it can be inferred that an ethanolic extract of $M$. officinalis is endowed with antigenotoxic/antimutagenic properties, and its use in pre-treatment diminishes the induction of DNA damage by an alkylant agent. Potential differences in antigenotoxic/antimutagenic activity by the various extracts still need to be clarified.

\section{Acknowledgments}

This work was supported by UNESC (Universidade do Extremo Sul Catarinense) and CNPq (Conselho Nacional de Desenvolvimento Científico eTecnológico).

\section{References}

Atoui AK, Mansouri A, Boskou G and Kefalas P (2005) Tea and herbal infusions: Their antioxidant activity and phenolic profile. Food Chem 89:27-36.

Azevedo L, Gomes JC, Stringheta PC, Gontijo AMMC, Padovani CR, Ribeiro LR and Salvadori DMF (2003) Black bean (Phaseolus vulgaris L.) as a protective agent against DNA damage in mice. Food Chem Toxicol 41:1671-1676.

Azevedo L, Lima PLA, Gomes JC, Stringheta PC, Ribeiro DA and Salvadori DMF (2007) Differential response related to genotoxicity between eggplant (Solanum melanogena) skin aqueous extract and its main purified anthocyanin (delphinidin) in vivo. Food Chem Toxicol 45:852-858.

Berhow M, Wagner E, Vaughn S and Plewa M (2000) Characterization and antimutagenic activity of soybean saponins. $\mathrm{Mu}-$ tat Res 448:11-22.

Boiteux S and Guillet M (2004) Abasic sites in DNA: Repair and biological consequences in Saccharomyces cerevisae. DNA Repair 3:1-12. 
Bresolin S and Vargas VMF (1993) Mutagenic potencies of medicinal plants screened in the Ames test. Phytother Res 7:260-262.

Canadanovic-Brunet J, Cetkovic G, Djilas S, Tumbas V, Bogdanovic G, Mandic A, Markov S, Cvetkovic D and Canadanovic V (2008) Radical scavenging, antibacterial, and antiproliferative activities of Melissa officinalis (L.) extracts. J Med Food 11:133-143.

Carnat AP, Carnat A, Fraisse D and Lamaison JL (1998) The aromatic and polyphenolic composition of lemon balm (Melissa officinalis L. subsp. officinalis) tea. Pharm Acta Helv 72:301-305.

Collins A, Dusinska M, Franklin M, Somorosyska M, Petroyska H, Duthie S, Fillion L, Panyotidis M, Raslová K and Vaughan N (1997) Comet assay in human biomonitoring studies: Reliability, validation, and applications. Environ Mol Mutagen 30:139-146.

Czeczot H and Kusztelak J (1993) A study of the genotoxic potential of flavonoids using short-term bacterial assays. Acta Biochim Pol 40:549-554.

Dastmalchi K, Dorman HJD, Oinonen PP, Darwis Y, Laakso I and Hiltunen R (2008) Chemical composition and in vitro antioxidative activity of a lemon balm (Melissa officinalis L.) extract. LWT - Food Sci Technol 41:391-400.

Doostdar H, Burke D and Mayer RT (2000) Bioflavonoids: Selective substrates and inhibitors for cytochrome P450 CYP1A and CYP1B1. Toxicology 144:31-38.

Edenharder R, Sager JW, Glatt H, Muckel E and Platt KL (2002) Protection by beverages, fruits, vegetables, herbs, and flavonoids against genotoxicity of 2 acetylaminofluoreno and 2-amino-1-methyl-6-phenylimidazol [4,5-6] pyridine (PhIP) in metabolically competent V79 cells. Mutat Res 521:57-72.

Farmacopéia Brasileira (2001) Farmacopéia Brasileira. 4th edition. Atheneu, São Paulo, 294 pp.

Fernandes JBF and Vargas VMF (2003) Mutagenic and antimutagenic potential of the medicinal plants $M$. laevigata and C. xanthocarpa. Phytother Res 17:269-273.

Franke SIR, Pra D, Erdtmann B, Henriques JAP and da Silva J (2005) Influence of orange juice over the genotoxicity induced by alkylating agents: An in vivo analysis. Mutagenesis 20:279-283

Furtado MA, Almeida LCF, Furtado RA, Cunha WR and Tavares DC (2008) Antimutagenicity of rosmarinic acid in Swiss mice evaluated by the micronucleus assay. Mutat Res 657:150-154

Furtado RA, Araújo FRR, Resende FA, Cunha WR and Tavares DC (2010) Protective effect of rosmarinic acido on V79 cells evaluated by the micronucleus and comet assays. J Appl Toxicol 30:254-259.

Geetha T, Malhotra V, Chopra K and Kaur IP (2005) Antimutagenic and antioxidant/prooxidant activity of Quercetin. Ind J Exp Biol 43:61-67.

Gomes-Carneiro MR, Dias DMM, De Oliveira ACAX and Paumgartten FJR (2005) Evaluation of mutagenic and antimutagenic activities of $\alpha$-bisabolol in the Salmonella/microsome assay. Mutat Res 585:105-112.

Guginski G, Luiz AP, Silva MS, Massaro M, Martins DF, Chaves J, Mattos RW, Silveira D, Ferreira VMM, Calixto JB, et al. (2009) Mechanisms involved in the antinociception caused by ethanolic extract obtained from the leaves of Melissa officinalis (lemon balm) in mice. Pharmacol Biochem Behav 93:10-16.

Harborn JB (1998) Phenolic compounds. In: Harborne JB (ed) Phytochemical Methods: A Guide to Modern Techniques of Plant Analysis. Chapman \& Hall, London, pp 40-106.

Hernández-Ceruelos A, Madrigal-Bujaidadar E and De La Cruz C (2002) Inhibitory effect of chamomile essential oil on the sister chromatid exchanges by daunorubicin and methyl methanesulfonate in mouse bone marrow. Toxicol Lett 135:103-110

Herodez SS, Hadolin M, Skerget M and Zeljko K (2003) Solvent extraction study of antioxidants from balm (Melissa officinalis L.) leaves. Food Chem 80:275-282.

Horvathova E, Slamenova D, Hlincikova L, Mandal TK, Gabelova A and Collins AR (1998) The nature and origin of DNA single-strand breaks determined with the comet assay. Mutat Res 409:163-171.

Ivanova D, Gerova D, Chervenkov T and Yankova T (2005) Polyphenols and antioxidant capacity of Bulgarian medicinal plants. J Ethnopharmacol 96:145-150.

Katalinic V, Milos M, Kulisic T and Jukic M (2006) Screening of 70 medicinal plant extracts for antioxidant capacity and total phenols. Food Chem 94:550-557.

Kelly C, Jewell C and O'Brien NM (2003) The effect of dietary supplementation with the citrus limonoids, limonin and nomilin on xenobiotic-metabolizing enzymes in the liver and small intestine of the rat. Nutr Res 23:681-690.

Lima PLA, Delmanto RD, Sugui MM, Eira AF, Salvadori DMF, Speit G and Ribeiro LR (2001) Letinula edodes (Berk.) Pegler (Shiitake) modulates genotoxic and mutagenic effects induced by alkylating agents in vivo. Mutat Res 496:23-32.

Mavournin KH, Blakey DH, Cimino MC, Salamone MF and Heddle J (1990) The in vivo micronucleus assay in mammalian bone marrow and peripheral blood. A report of the U.S. Environmental Protection Agency Gene-Tox Program. Mutat Res 232:29-80.

Mimica-Dukic N, Bozin B, Socovik M and Simin N (2004) Antimicrobial and antioxidant activities of Melissa officinalis L. (Lamiacea) essential oil. J Agric Food Chem 52:2485-2489.

Müzell DP (2006) Propriedades biológicas de extratos de Melissa officinalis L. (lamiaceae) em ratos wistar. Dissertação de Mestrado em Biologia Celular e Molecular, Faculdade de Biociências da Pontifícia Universidade Católica do Rio Grande do Sul, Porto Alegre, 70 pp.

Patel D, Shukla S and Gupta S (2007) Apigenin and cancer chemoprevention: Progress, potential and promise. Int $\mathrm{J}$ Oncol 30:233-245.

Pereira P, Tysca D, Oliveira P, Da Silva-Brum LF, Picada JN and Ardenghi P (2005) Neurobehavioral and genotoxic aspects of rosmarinic acid. Pharmacol Res 52:199-203.

Pereira RP, Fachineto R, Prestes AS, Puntel RL, Boschetti TK, Athayde ML, Büerguer ME, Morel AF, Morsch VM and Rocha JBT (2009) Antioxidant effects of different extracts from Melissa officinalis, Matricaria recutita and Cymbopogon citratus. Neurochem Res 34:973-983.

Pérez-Pérez EM, Rodrígez-Malaver AJ, Padilla N, Medina-Ramírez G and Dávila J (2006) Antioxidant capacity of crude extracts from clones of banana and plane species. J Med Food 9:517-523. 
Sá-Ferreira ICF and Vargas VMF (1999) Mutagenicity of medicinal plant extracts in Salmonella/microsome assay. Phytother Res 13:397-400.

Salah SM and Jäger AK (2005) Screening of traditionally used Lebanese herbs for neurological activities. J Ethnopharmacol 97:145-149.

Singh NP, McCoy MT, Tice RR and Schneider EL (1988) A simple technique for quantification of low levels of DNA damage in individual cells. Exp Cell Res 175:184-191.

Souza AC, Alviano DS, Alves PB, Alviano CS and Gattass CR (2004) Melissa officinalis L. essential oil: Antitumoral and antioxidant activities. J Pharm Pharmacol 56:677-681.

Surh Y and Fergunson LR (2003) Dietary and medicinal antimutagens and anticarcinogens: Molecular mechanisms and chemopreventive potential - Highlights of a symposium. Mutat Res 485:1-8.

Szaefer H, Cichocki M, Brauze D and Baer-Dubowska W (2004) Alteration in phase I and II enzyme activities and polycyclic aromatic hydrocarbons-DNA adduct formation by plant phenolics in mouse epidermis. Nutr Cancer 48:70-77.
Tovart RT (2009) Clinical approach to clinical herbal toxicity. Sem Diagn Pathol 26:28-37.

Villela IV, Oliveira IMde, Silva J da and Henriques JAP (2006) DNA damage and repair in haemolymph cells of golden mussel (Limnoperna fortunei) exposed to environmental contaminants. Mutat Res 605:78-86.

Wagner H and Bladt S (2009) Plant Drug Analysis: A Thin Layer Chromatography Atlas. 2nd edition. Springer, Heidelberg, $384 \mathrm{pp}$.

Waters MD, Brady AL, Stack HF and Brockman HE (1990) Antimutagenicity profiles for some model compounds. Mutat Res 238:57-85.

World Cancer Research Fund (2008) Food, nutrition, and the prevention of cancer: A global perspective. Nutrition 24:393398.

Associate Editor: Catarina S. Takahashi

License information: This is an open-access article distributed under the terms of the Creative Commons Attribution License, which permits unrestricted use, distribution, and reproduction in any medium, provided the original work is properly cited. 